\title{
Implementasi Transmisi Sinyal TV pada Media Transmisi Fiber Optik Singlemode
}

\author{
Nadhia Syafira Arifianti ${ }^{1}$, Yoyok Heru Prasetyo $I^{2}$, Koesmarijanto ${ }^{3}$ \\ ${ }_{1,2}$ Program Studi Jaringan Telekomunikasi Digital, \\ Jurusan Teknik Elektro, Politeknik Negeri Malang, Indonesia \\ ${ }^{3}$ Program Studi Teknik Telekomunikasi, \\ Jurusan Teknik Elektro, Politeknik Negeri Malang, Indonesia \\ 1.nadhiasyafiraa@gmail.com ${ }^{2}$ yoyok.heru@polinema.ac.id , ${ }^{3}$ koesmarijanto@polinema.ac.id
}

\begin{abstract}
The results of TV service output using the Hybrid Fiber Coaxial system obtained a signal quality of $74 \%$ with a total of 49 channels. The attenuation with input 1 parabolic antenna receiver decoder using $200 \mathrm{~cm}$ fiber optic obtained a loss of $1.79 \mathrm{~dB}$ and at length of $2 \mathrm{~km}$ the loss is $8.91 \mathrm{~dB}$. Whereas with the input of 2 decoder, a parabolic antenna receiver using $200 \mathrm{~cm}$ fiber optic, the value of losses is $1.93 \mathrm{~dB}$ and at $2 \mathrm{~km}$ the loss is $9.83 \mathrm{~dB}$. The average deviation of RGB errors in the largest television image output results is Green by $0.226 \%$ and the lowest error deviation is Red at $0.148 \%$. The effect of audio and video output before adding fiber optic devices is obtained, the audio output voltage value is $1.792 \mathrm{~V}$ and the video output voltage value is $2.591 \mathrm{~V}$. After adding the fiber optic device the value of the output voltage with 1 television output and 1 decoder receiver at a length of $200 \mathrm{~cm}$ audio is $1.144 \mathrm{~V}$ and video is $1.167 \mathrm{~V}$ while at a length of $2 \mathrm{~km}$ the audio is $0.834 \mathrm{~V}$ and the video is $1.005 \mathrm{~V}$.
\end{abstract}

Keywords — Hybrid Fiber Coaxial, TV Broadcast service, Fiber Transmitter, Fiber Receiver

Abstrak - Hasil output layanan TV menggunakan sistem Hybrid Fiber Coaxial didapatkan kualitas sinyal sebesar $74 \%$ dengan jumlah channel sebanyak 49 channel. Nilai redaman dengan input 1 decoder receiver antena parabola menggunakan panjang kabel fiber optik $200 \mathrm{~cm}$ didapatkan nilai rugi-rugi 1,79 dB dan pada panjang kabel $2 \mathrm{~km}$ nilai rugi-rugi sebesar 8,91 dB. Sedangkan dengan input 2 decoder receiver antena parabola menggunakan panjang kabel fiber optik $200 \mathrm{~cm}$ didapatkan nilai rugi-rugi 1,93 dB dan pada panjang kabel $2 \mathrm{~km}$ nilai rugi-rugi sebesar 9,83 dB. Rata-rata deviasi error RGB pada hasil keluaran gambar televisi terbesar adalah Green sebesar $0,226 \%$ dan deviasi error terendah adalah Red sebesar $0,148 \%$. Pengaruh output audio dan video sebelum ditambahkan perangkat fiber optik didapatkan, nilai tegangan output audio 1,792 V dan nilai tegangan output video 2,591 V. Setelah ditambahkan perangkat fiber optik nilai Tegangan output dengan 1 output televisi dan 1 decoder receiver pada panjang $200 \mathrm{~cm}$ audio $1,144 \mathrm{~V}$ dan video $1,167 \mathrm{~V}$ sedangkan pada panjang $2 \mathrm{~km}$ audio sebesar $0,834 \mathrm{~V}$ dan video sebesar $1,005 \mathrm{~V}$.

Kata kunci - Hybrid Fiber Coaxial, layanan TV Broadcast, Fiber Transmitter, Fiber Receiver

\section{PENDAHULUAN}

Dalam era informasi, layanan sistem transmisi berpita lebar (broadband) sangat dibutuhkan untuk menunjang kualitas aliran informasi antara pelanggan dan kebutuhan jumlah pelanggan akan akses informasi yang tersedia [1]. Sistem komunikasi fiber optic merupakan system yang dapat diterapkan untuk mengatasi permasalahan tersebut dengan keunggulan memiliki kapasitas pembawa informasi yang tinggi inilah menjadikan sistem ini sebagai kunci utama dari telekomunikasi modern[2]. Pada teknologi fiber optik telah dikembangkan hubungan transmisi dengan mengintegrasikan antara sistem komunikasi gelombang radio dengan sistem komunikasi serat optik[1].

Dengan meningkatnya kebutuhan layanan masyarakat modern sehingga dibutuhkan sebuah teknologi telekomunikasi yang memberikan performansi layanan yang tinggi. Teknologi telekomunikasi pun beragam seperti telekomunikasi suara, video, data atau yang lebih dikenal dengan internet[3]. Teknologi hybrid fiber coaxial, merupakan satu teknologi yang dikembangkan untuk menjawab tuntutan tersebut, dimana teknologi ini secara teoritis mengirimkan berbagai layanan secara sekaligus (multiservice) baik itu suara, gambar, data dan video[4]. Selain itu komunikasi hybrid (kawat dan nirkabel) yang digunakan dalam teknologi ini menjanjikan solusi untuk permintaan bandwidth yang berkembang pesat dalam komunikasi modern[5].

Penggunaan teknologi hybrid fiber coaxial telah digunakan dalam bidang telekomunikasi, khususnya dari antena ke BTS indoor[6]. Dalam penerapannya, perlu adanya fitur tambahan yang mampu menyediakan layanan TV Broadcast dengan channel pilihan sendiri dengan efisiensi perangkat di sisi user, low cost, serta dapat menampung user dalam jumlah yang banyak. HFC merupakan teknologi jaringan akses TV Broadcast yang dibangun atas dasar kombinasi jaringan optik dan koaksial. Dengan HFC, memungkinkan kita dapat merasakan layanan TV dengan pemakaian antena bersama yang memiliki keunggulan dalam kapasitas user. Keunggulan jaringan HFC ini adalah mengkombinasikan keunggulan lebar pita frekuensi pada serat optik yang sangat lebar, dan sifat shared kabel koaksial dengan menggunakan splitter[7]. 
Jurnal Jaringan Telekomunikasi (Jurnal Jartel) E-ISSN:2654-6531 P- ISSN: 2407-0807 Vol. 10, No.3 (2020) 156-161

Penelitian sebelumnya dikatakan bahwa didapatkan nilai power input Fiber Node yang memenuhi kinerja layanan TV yakni sebesar -5 dBm sampai dengan -27 dBm. Nilai CNR yang didapatkan sebesar 47,7 dB sehingga hasil pengukuran kualitas HFC pada jaringan FTTH adalah baik dan memenuhi standar. Dari hasil pengujian didapatkan nilai kapasitas pada jaringan HFC tanpa integrasi FTTH sebanyak 32 pelanggan, sedangkan pada jaringan HFC yang diintegrasikan pada FTTH memiliki kapasitas pelanggan yang lebih banyak yakni 256 pelanggan[7].

Dengan hasil tersebut, maka pada penelitian ini penulis akan melakukan implementasi transmisi sinyal TV pada media transmisi fiber optik singlemode guna menguji kelayakan media fiber optik (kabel fiber optik) dengan menganalisis nilai parameter performansi output pada TV analog, selain itu penggunaan serat singlemode dipilih dalam penelitian ini karena pada dasarnya serat singlemode memiliki karakteristik kehilangan daya yang lebih rendah daripada serat multimode, yang berarti cahaya dapat menempuh jarak yang lebih jauh daripada serat multimode.

\section{METODE PENELITIAN}

\section{A. Rancangan Penelitian}

Tahapan penelitian yang akan dilakukan dinyatakan dengan diagram alir yang tertera pada Gambar 1 .

Tahapan pertama yaitu melakukan perumusan masalah serta tujuan yang akan digunakan dalam penelitian ini..

Tahapan kedua adalah studi pustaka yang merupakan kegiatan mencai referensi dan data-data penunjang.

Tahap ketiga adalah menentukan parameter yang akan digunakan sebagai tolak ukur uji coba pada sistem yang akan diterapkan.

Tahapan keempat yaitu perencanaan hardware sistem, dalam perencaan ini meliputi pengecekan perangkat, sistem output dan input serta perkiraan letak perangkat yang diperlukan.

Tahapan kelima merupakan pengujian sistem, pada tahapan ini dilakukan implementasi alat sesuai dengan rancangan sistem yang telah dibuat. kemudian akan dilakukan pengujian sistem.

Tahapan keenam yaitu analisa sistem, pada tahap ini dilakukan analisa sistem kerja diantaranya apakah sistem dapat berjalan sesuai dengan yang telah direncanakan, proses modulasi sinyal audio video menjadi sinyal optik begitupun sebaliknya, hasil output yang didapatkan dari sistem.

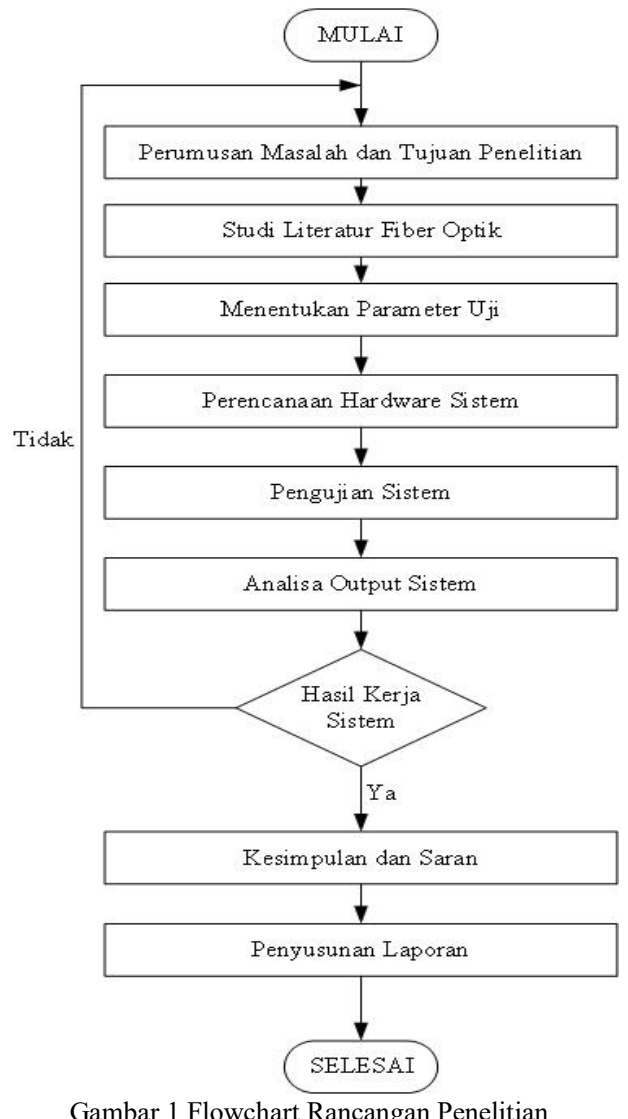

Tahapan ketujuh yaitu hasil sistem kerja, jika hasil sistem kerja yang diperoleh memenuhi sistem yang telah direncanakan maka dapat ditarik kesimpulan, apabila hasil sistem kerja yang diperoleh tidak memenuhi sistem yang telah direncanakan maka akan dilakukan pengecekan ulang pada perancangan hardware, perancagan desain dan pengecekan pada sistem yang telah dibuat.

Tahapan kedelapan yaitu pembuatan kesimpulan, pembuatan kesimpulan ini dapat dilakukan apabila hasil dari sistem kerja telah sesuai dengan perancangan sistem yang telah dibuat.

\section{B. Rancangan Sistem}

Penelitian ini menggunakan teknologi Hybrid Fiber Coaxial untuk Transmisi sinyal TV pada media fiber optic Singlemode. Parameter dari simulasi dan implementasi dipilih sehingga sesuai dengan standar kelayakan Teknologi Hybrid Fiber Coaxial. Gambar 2 merupakan rancangan yang akan diterapkan.

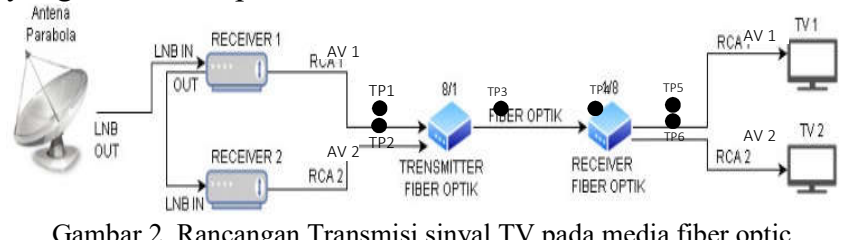

Gambar 2. Rancangan Transmisi sinyal TV pada media fiber optic Singlemode

Stasiun bumi yang digunakan untuk satu arah yang sering digunakan untuk menerima siaran televisi ataupun sebagai 
radio, perangkat - perangkatnya terdiri dari antena reflector, Low Noise Block (LNB), kabel coaxial. Antena berfungsi menerima sinyal berupa gelombang elektromagnetik yang bermodulasi RF dari satelit. Low Noise Block (LNB) berfungsi menerima gabungan sinyal yang dipantulkan dari piringan/dish. Kabel coaxial berfungsi sebagai penghubung dari LNB ke perangkat yang menampilkan siaran televisi.

Sumber informasi berupa gelombang elektromagnetik yang bermodulasi RF dari satelit dengan frekuensi up-link 4 $\mathrm{GHz}$ dan frekuensi downlink $6 \mathrm{GHz}$ pada LNB C-Band dan frekuensi $12 \mathrm{GHz}$ sampai dengan $14 \mathrm{GHz}$ pada LNB Kuband. Elemen pusat di pusat parabola yang berbentuk tanduk adalah low noise blockdown converter (LNB). LNB memperkuat sinyal radio memantul ke parabola dan menyaring gangguan (sinyal radio tidak membawa program). LNB menewati penguat, menyaring sinyal ke receiver satelit didalam rumah pelanggan.

Sinyal berbentuk sinyal baseband audio dan video yang telah dimodulasi akan diteruskan ke perangkat Fiber Transmitter untuk dikonversi menjadi sinyal optik dengan sumber cahaya berupa laser. Informasi yang keluar dari receiver akan ditransmisikan menjadi layanan audio video, kemudian akan ditransmisikan layanan TV broadcast yang bersumber dari transmitter.

\section{PENGUJIAN DAN ANALISIS}

\section{A. Implementasi Instalasi Antena Parabola}

Instalasi Antena Parabola secara umum berfungsi untuk mentransmisikan berbagai data, seperti sinyal telepon, sinyal radio, sinyal televisi, serta beragam data lain yang dapat ditransmisikan melalui gelombang, dalam hal ini antena parabola digunakan sebagai alat untuk menerima siaran televisi satelit. Hasil implementasi Instalasi Antena Parabola dapat dilihat pada gambar 3 .

Percobaan kali ini antena parabola dipasang dan di letakkan di area Gedung AH Lantai 1 Politeknik Negeri Malang, dimana pada daerah diletakkannya antena parabola tersebut banyak sekali halangan sehingga kekuatan sinyal yang didapatkan hanya sebesar $74 \%$ dengan total channel yang didapatkan sebanyak 49 channel.

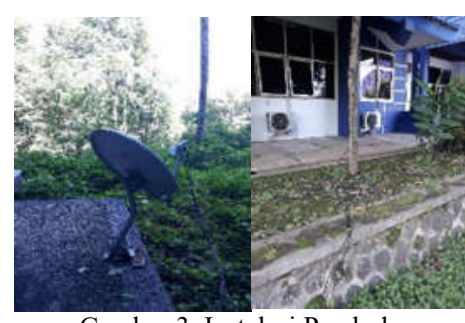

Gambar 3. Instalasi Parabola

\section{B. Implementasi Perangkat Pengirim}

Perangkat Pengirim berfungsi mengirimkan informasi berupa audio dan video berasal dari antena parabola yang dikirimkan berupa cahaya. Pada sistem pengirim terdapat jack input RGB, dan jack output Fiber Optik. Hasil implementasi sistem pengirim dapat dilihat pada gambar 4

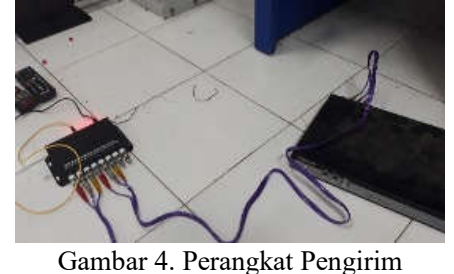

\section{Implementasi Perangkat Penerima}

Sistem penerima berfungsi menerima informasi dalam bentuk cahaya yang telah dikirimkan oleh transmitter serta mengubah informasi menjadi audio, video kembali. Pada sistem penerima terdapat jack input fiber optic dan jack output RGB. Hasil implementasi sistem penerima dapat dilihat pada Gambar 5

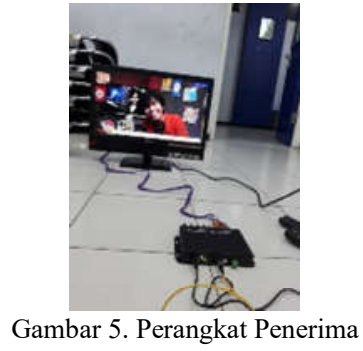

\section{Implementasi Output Sistem}

Output sistem berfungsi mengetahui bagaimana performansi dari transmisi menggunakan fiber optik. Pada output sistem terdapat 2 unit televisi. Hasil implementasi sistem penerima dapat dilihat pada gambar 6 .

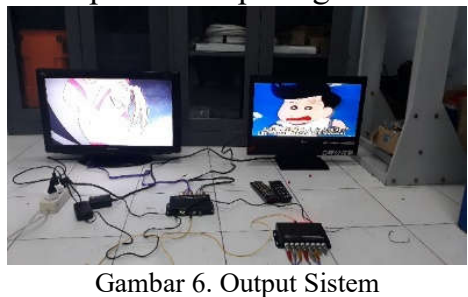

E. Analisa Perbedaan Nilai Tegangan Output Sebelum ditambahkan Fiber Optik dengan Setelah ditambahkan Fiber Optik

Pengujian ini bertujuan untuk mengetahui perbedaan tegangan keluaran dengan atau tanpa fiber optik dari sistem komunikasi menggunakan media fiber optik dengan tipe kabel fiber optik singlemode dan panjang gelombang 1310 $\mathrm{nm}$. Pada pengujian ini digunakan input yang berasal dari Antena Parabola. Kemudian panjang kabel fiber optik dibuat bervariasi untuk mengetahui niai perbedaan daya output di setiap variasi panjang yaitu $2 \mathrm{~m}, 5 \mathrm{~m}, 8 \mathrm{~m}, 15 \mathrm{~m}, 20 \mathrm{~m}, 410$ $\mathrm{m}, 500 \mathrm{~m}, 1000 \mathrm{~m}$ dan $2000 \mathrm{~m}$ dan output sistem yang berupa Audio dan Video. Alat yang digunakan dalam pengujian ini yaitu Multimeter untuk mendapatkan nilai tegangan output.

Pengujian dilakukan pengukuran menggunakan jumlah input yang berbeda yakni menggunakan 1 output televisi dengan 1 decoder receiver dan 2 output televisi dengan 2 decoder receiver. 
TABEL I.

NILAI TEGANGAN OUTPUT DARI SATELIT TELEVISI (TP1) DAN OUTPUT RECEIVER FIBER OPTIK (TP 5)

\begin{tabular}{|c|c|c|c|c|}
\hline \multirow{2}{*}{$\begin{array}{c}\text { Panjang Kabel } \\
\text { (m) }\end{array}$} & \multicolumn{2}{|c|}{$\begin{array}{c}\text { TP 1 } \\
\text { (Volt) }\end{array}$} & \multicolumn{2}{|c|}{$\begin{array}{c}\text { TP 5 } \\
\text { (Volt) }\end{array}$} \\
\hline & Video & Audio & Video & Audio \\
\hline 2 & 2,591 & 1,792 & 1,167 & 1,144 \\
\hline 5 & 2,591 & 1,792 & 1,167 & 1,144 \\
\hline 8 & 2,591 & 1,792 & 1,167 & 1,144 \\
\hline 15 & 2,591 & 1,792 & 1,167 & 1,144 \\
\hline 20 & 2,591 & 1,792 & 1,167 & 1,144 \\
\hline 410 & 2,591 & 1,792 & 1,141 & 1,121 \\
\hline 500 & 2,591 & 1,792 & 1,141 & 1,121 \\
\hline 1000 & 2,591 & 1,792 & 1,022 & 0,984 \\
\hline 2000 & 2,591 & 1,792 & 1,005 & 0,834 \\
\hline
\end{tabular}

Kemudian dilakukan pengukuran untuk nilai daya dengan menggunakan 2 output televisi dengan 2 decoder receiver.

TABEL II.

Nilai Tegangan OUtPut RECEIVER FiBer OPTIK PADA TeleVisi 1 (TP 5) DAN TELEVISI 2 (TP 6)

\begin{tabular}{ccccc}
\hline $\begin{array}{c}\text { Panjang } \\
\text { Kabel } \\
(\mathrm{m})\end{array}$ & $\begin{array}{c}\text { Nilai Daya pada TP 5 } \\
\text { (Watt) }\end{array}$ & \multicolumn{2}{c}{$\begin{array}{c}\text { Nilai Daya pada TP 6 } \\
\text { (Watt) }\end{array}$} \\
\cline { 2 - 5 } & Video & Audio & Video & Audio \\
\hline 2 & 1,148 & 1,121 & 1,148 & 1,121 \\
\hline 5 & 1,148 & 1,121 & 1,148 & 1,121 \\
\hline 8 & 1,148 & 1,121 & 1,148 & 1,121 \\
\hline 15 & 1,148 & 1,121 & 1,148 & 1,121 \\
\hline 20 & 1,148 & 1,121 & 1,148 & 1,121 \\
\hline 410 & 0,984 & 0,696 & 0,984 & 0,696 \\
\hline 500 & 0,984 & 0,696 & 0,984 & 0,696 \\
\hline 1000 & 0,834 & 0,497 & 0,834 & 0,497 \\
\hline 2000 & 0,672 & 0,368 & 0,672 & 0,368 \\
\hline
\end{tabular}

Tabel 2. tersebut menjelaskan bahwa terjadi penurunan tegangan output dari TP 1 dan TP 2 yang belum disambungkan dengan kabel fiber optik dengan TP 5 dan 6 yang telah dilewatkan pada media transmisi fiber optik, hal tersebut dapat terjadi karena semakin panjang media komunikasi yang dilewati. pada panjang kabel 2 meter didapatkan niai tegangan output pada Video sebesar 1,148 Volt dan output audio sebesar 1,121Volt. Sedangkan pada saat panjang kabel 2000 meter atau $2 \mathrm{~km}$ didapatkan niai daya output pada Video sebesar 0,672 Volt dan output audio sebesar 0,368 Volt.

F. Analisa pengaruh variasi panjang kabel Fiber Optik pada sistem komunikasi Fiber Optik terhadap Rugi-rugi kabel fiber optik singlemode

$$
P_{T}=P_{S}-P_{r}
$$

Keterangan :

$\mathrm{P}_{\mathrm{T}} \quad=$ Optical power transmit/rugi-rugi total $(\mathrm{dB})$

$\mathrm{P}_{\mathrm{s}} \quad=$ Optical power source $(\mathrm{dBm})$

$\mathrm{P}_{\mathrm{r}} \quad=$ Optical power receiver $(\mathrm{dBm})$

Nilai daya output yang didapatkan dari proses pengukuran digunakan untuk menghitung nilai rugi-rugi dengan persamaan nilai rugi-rugi kabel serat optik singlemode. Panjang kabel fiber optik dibuat bervariasi untuk mengetahui niai perbedaan daya output di setiap variasi panjang yaitu $2 \mathrm{~m}, 5 \mathrm{~m}, 8 \mathrm{~m}, 15 \mathrm{~m}, 20 \mathrm{~m}, 410 \mathrm{~m}, 500$ $\mathrm{m}, 1000 \mathrm{~m}$ dan $2000 \mathrm{~m}$. Alat yang digunakan dalam pengujian ini yaitu Optical Power Meter. Nilai perhitungan untuk rugi-rugi kabel serat optik singlemode pada percobaan menggunakan antena parabola dengan output 1 buah Televisi ditunjukkan pada Tabel 3.

TABEL III.

Hasil Perhitungan Nilai Redaman media TRANSmisi Fiber Optik DENGAN 1 OUTPUT AV

\begin{tabular}{cccc}
\hline $\begin{array}{c}\text { Panjang } \\
\text { Kabel }(\mathrm{m})\end{array}$ & $\begin{array}{c}\text { Nilai Daya Input } \\
\left(\mathrm{P}_{\text {in }}\right) \\
\text { TP 3 }(\mathrm{dBm})\end{array}$ & $\begin{array}{c}\text { Nilai Daya Output } \\
\left(\mathrm{P}_{\text {out }}\right) \\
\text { TP } 4(\mathrm{dBm})\end{array}$ & $\begin{array}{c}\text { Loss } \\
(\mathrm{dB})\end{array}$ \\
\hline 2 & $-04,21$ & $-06,00$ & 1,79 \\
\hline 5 & $-04,21$ & $-06,67$ & 2,46 \\
\hline 8 & $-04,21$ & -06.83 & 2,62 \\
\hline 15 & $-04,21$ & $-07,05$ & 2,84 \\
\hline 20 & $-04,21$ & $-07,28$ & 3,07 \\
\hline 410 & $-04,21$ & $-07,94$ & 3,73 \\
\hline 500 & $-04,21$ & $-10,32$ & 6,11 \\
\hline 1000 & $-04,21$ & $-12,92$ & 8,71 \\
\hline 2000 & $-04,21$ & $-13,16$ & 8,91 \\
\hline
\end{tabular}

Kemudian dilakukan pengukuran untuk nilai redaman dengan menggunakan 2 output televisi dengan 2 decoder receiver.

TABEL IV.

Hasil Perhitungan Nilai REDAMAN MEdia Transmisi Fiber OPTIK DENGAN 2 OUTPUT AV

\begin{tabular}{cccc}
\hline $\begin{array}{c}\text { Panjang } \\
\text { Kabel }(\mathrm{m})\end{array}$ & $\begin{array}{c}\text { Nilai Daya Input } \\
\left(\mathrm{P}_{\text {in }}\right) \\
\mathrm{TP} 3(\mathrm{dBm})\end{array}$ & $\begin{array}{c}\text { Nilai Daya Output } \\
\left(\mathrm{P}_{\text {out }}\right) \\
\text { TP 4 }(\mathrm{dBm})\end{array}$ & $\begin{array}{c}\text { Loss } \\
(\mathrm{dB})\end{array}$ \\
\hline 2 & $-05,12$ & $-07,05$ & 1,93 \\
\hline 5 & $-05,12$ & $-07,28$ & 2,16 \\
\hline 8 & $-05,12$ & $-07,94$ & 2,82 \\
\hline 15 & $-05,12$ & $-08,35$ & 3,32 \\
\hline 20 & $-05,12$ & $-09,39$ & 4,27 \\
\hline 410 & $-05,12$ & $-10,32$ & 5,2 \\
\hline 500 & $-05,12$ & $-12,47$ & 7,35 \\
\hline 1000 & $-05,12$ & $-13,16$ & 8,04 \\
\hline 2000 & $-05,12$ & $-14,95$ & 9,83 \\
\hline
\end{tabular}

Tabel 4. menunjukkan nilai rugi-rugi terbesar sebesar 9,83 dB pada panjang kabel $200000 \mathrm{~cm}$, sedangkan nilai rugi-rugi terkecil sebesar $1,93 \mathrm{~dB}$ pada panjang kabel 200 $\mathrm{cm}$

G. Analisa perhitungan Power Link Budget pada sistem komunikasi Fiber Optik

$$
\alpha_{\text {total }}=L \times \alpha f+N c \times \alpha s+N s \times \alpha s+N s p \times a s p
$$

Keterangan :

$$
\begin{array}{ll}
\alpha \text { tot } & =\text { redaman total saluran }(\mathrm{dB}) \\
\mathrm{L} & =\text { panjang serat optik }(\mathrm{km}) \\
\alpha \mathrm{f} & =\text { redaman serat optik }(\mathrm{dB}) \\
\mathrm{Nc} & =\text { jumlah konektor } \\
\alpha \mathrm{c} & =\text { redaman konektor }(\mathrm{dB} / \text { konektor }) \\
\mathrm{Ns} & =\text { jumlah sambungan } \\
\alpha \mathrm{s} & =\text { redaman sambungan }(\mathrm{dB} / \text { sambungan })
\end{array}
$$

Perhitungan Power Link Budget. perhitungan ini bertujuan sebagai penentu suatu sistem komunikasi optik dapat berjalan dengan baik atau tidak. Power budget menjamin agar penerima dapat menerima daya optik sinyal yang diperlukan. Perhitungan Power Link Budget dihitung berdasarkan variasi Panjang kabel yang diubah-ubah yakni $2 \mathrm{~m}, 5 \mathrm{~m}, 8 \mathrm{~m}, 15 \mathrm{~m}, 20 \mathrm{~m}, 410 \mathrm{~m}, 500 \mathrm{~m}, 1000 \mathrm{~m}$ dan 2000 $\mathrm{m}$ dan perbedaan jumlah output televisi.

1) Menggunakan 1 decoder receiver dan 1 output televisi 
Jurnal Jaringan Telekomunikasi (Jurnal Jartel) E-ISSN:2654-6531 P- ISSN: 2407-0807 Vol. 10, No.3 (2020) 156-161

Nilai perhitungan untuk Power Link Budget pada percobaan menggunakan input Antena Parabola dengan output 1 buah Televisi ditunjukkan pada Tabel 5 TABEL V.

NiLAI PERHITUNGAN UNTUK POWER LINK BUdGET PADA PERCOBAAN MENGGUNAKAN INPUT ANTENA PARABOLA DENGAN OUTPUT 1 BUAH

\begin{tabular}{ccccc}
\hline $\begin{array}{c}\text { Panjang } \\
\text { Kabel } \\
(\mathbf{m})\end{array}$ & $\begin{array}{c}\text { Nilai } \mathbf{P}_{\text {out }} \\
\text { Transmitter } \\
(\mathbf{d B m})\end{array}$ & $\begin{array}{c}\text { TELEVISI } \\
\text { Nilai } \mathbf{P}_{\text {out }} \\
\text { Receiver } \\
(\mathbf{d B m})\end{array}$ & $\begin{array}{c}\text { Loss } \\
(\mathbf{d B})\end{array}$ & $\begin{array}{c}\text { Power Link } \\
\text { Budget } \\
(\mathbf{d B})\end{array}$ \\
\hline 2 & $-04,21$ & $-06,00$ & 1,79 & $-4,713$ \\
\hline 5 & $-04,21$ & $-06,67$ & 2,46 & $-4,722$ \\
\hline 8 & $-04,21$ & -06.83 & 2,62 & $-5,130$ \\
\hline 15 & $-04,21$ & $-07,05$ & 2,84 & $-5,352$ \\
\hline 20 & $-04,21$ & $-07,28$ & 3,07 & $-5,371$ \\
\hline 410 & $-04,21$ & $-07,94$ & 3,73 & $-6,239$ \\
\hline 500 & $-04,21$ & $-10,32$ & 6,11 & $-7,765$ \\
\hline 1000 & $-04,21$ & $-12,92$ & 8,71 & $-13,42$ \\
\hline 2000 & $-04,21$ & $-13,16$ & 8,91 & $-22,53$ \\
\hline
\end{tabular}

2) Menggunakan 2 decoder receiver dan 2 output televisi

Perhitungan Power Link Budget dihitung berdasarkan variasi panjang kabel fiber optik yakni $2 \mathrm{~m}, 5 \mathrm{~m}, 8 \mathrm{~m}, 15 \mathrm{~m}$, $20 \mathrm{~m}, 410 \mathrm{~m}, 500 \mathrm{~m}, 1000 \mathrm{~m}$ dan $2000 \mathrm{~m}$. Nilai perhitungan untuk Power Link Budget pada percobaan menggunakan input Antena Parabola dengan output 2 buah Televisi ditunjukkan pada Tabel 6

$$
\text { TABEL VI. }
$$

NilaI PERHITUNGAN UNTUK POWER LINK BUDGET PADA PERCOBAAN MENGGUNAKAN INPUT ANTENA PARABOLA DENGAN OUTPUT 2 BUAH

\begin{tabular}{ccccc}
\hline $\begin{array}{c}\text { Panjang } \\
\text { Kabel } \\
(\mathbf{m})\end{array}$ & $\begin{array}{c}\text { Nilai } \mathbf{P}_{\text {out }} \\
\text { Transmitter } \\
(\mathbf{d B m})\end{array}$ & $\begin{array}{c}\text { NeLeVISI } \\
\text { Receiver } \\
(\mathbf{d B m})\end{array}$ & $\begin{array}{c}\text { Loss } \\
(\mathbf{d B})\end{array}$ & $\begin{array}{c}\text { Power Link } \\
\text { Budget } \\
\mathbf{( d B})\end{array}$ \\
\hline 2 & $-05,12$ & $-07,05$ & 1,93 & $-5,623$ \\
\hline 5 & $-05,12$ & $-07,28$ & 2,16 & $-5,630$ \\
\hline 8 & $-05,12$ & $-07,94$ & 2,82 & $-6,042$ \\
\hline 15 & $-05,12$ & $-08,35$ & 3,32 & $-6,269$ \\
\hline 20 & $-05,12$ & $-09,39$ & 4,27 & $-6,305$ \\
\hline 410 & $-05,12$ & $-10,32$ & 5,2 & $-7,752$ \\
\hline 500 & $-05,12$ & $-12,47$ & 7,35 & $-9,295$ \\
\hline 1000 & $-05,12$ & $-13,16$ & 8,04 & $-13,66$ \\
\hline 2000 & $-05,12$ & $-14,95$ & 9,83 & $-25,28$ \\
\hline
\end{tabular}

H. Analisa Perbandingan Hasil Tampilan Gambar berdasarkan nilai RGB Sebelum menggunakan Fiber Optik dengan Setelah ditambahkan Fiber Optik

Percobaan pertama, dilakukan pengujian tanpa menggunakan fiber optik, dimana pada keluaran decoder receiver antena parabola yang berupa kabel RCA dihubungkan secara langsung pada televisi, dari percobaan tersebut didapatkan channel TV sebanyak 49 channel.

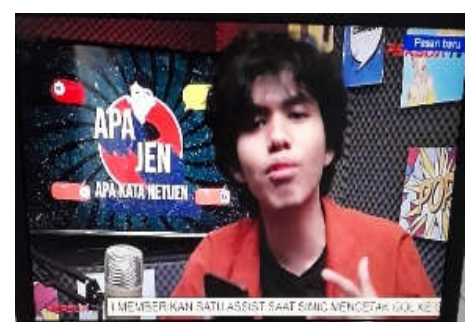

Gambar 7 Tampilan Gambar sebelum menggunakan fiber optik
Selanjutnya dilakukan penambahan kabel fiber optik, dengan variasi panjang kabel yakni $2 \mathrm{~m}, 5 \mathrm{~m}, 8 \mathrm{~m}, 15 \mathrm{~m}, 20$ m, 410 m, 500 m, $1000 \mathrm{~m}$ dan 2000 m. Pada percobaan ini keluaran decoder receiver yang berupa kabel RCA disambungkan pada transmitter fiber optik menggunakan connector RCA to BNC. Antara Transmitter Fiber Optik dengan Receiver Fiber Optik dihubungkan dengan kabel fiber optik singlemode dengan panjang gelombang $1310 \mathrm{~nm}$, panjang kabel fiber optik dibuat bervariasi guna mengetahui hasil performansi sistem. Dari percobaan tersebut didapatkan Channel yang dapat terdeteksi sebanyak 49 channel perbedaannya yaitu setelah ditambahkan kabel dan perangkat media converter transmitter dan receiver fiber optik suara yang keluar semakin kecil, hal itu dapat dilihat bahwa hasil nilai daya output pada audio semakin kecil.

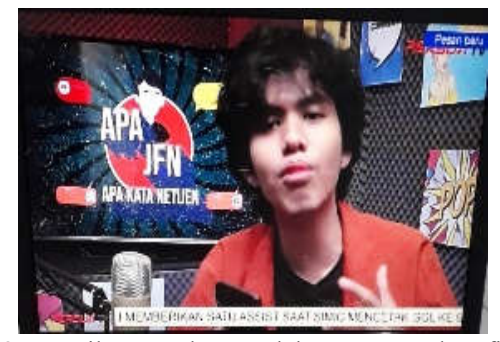

Gambar 8 Tampilan Gambar setelah menggunakan fiber optik

Hasil tampilan gambar sebelum ditambahkan fiber optik dengan setelah ditambahkan fiber optik terlihat tidak ada perubahan secara kasat mata. Namun setelah dilakukan analisis deviasi nilai RGB pada gambar sebelum ditambahkan fiber optik dengan setelah ditambahkan fiber optik menggunakan aplikasi matlab didapatkan hasil nilai prosentase deviasi error tiap warna yang ditunjukkan pada Tabel 7

TABEL VII.

OLAH RGB PADA GAMBAR KELUARAN TELEVISI SEBELUM MENGGUNAKAN FIBER OPTIK DENGAN SESUDAH MENGGUNAKAN FIBER OPTIK

\begin{tabular}{ccccccccc}
\hline $\begin{array}{c}\text { Setelah menggunakan } \\
\text { Fiber Optik }\end{array}$ & \multicolumn{2}{c}{$\begin{array}{c}\text { Sebelum menggunakan } \\
\text { Fiber Optik }\end{array}$} & $\begin{array}{c}\text { Deviasi } \\
\text { R }\end{array}$ & $\begin{array}{c}\text { Deviasi } \\
\text { G }\end{array}$ & $\begin{array}{c}\text { Deviasi } \\
\text { B }\end{array}$ \\
\hline R1 & G1 & B1 & R2 & G2 & B2 & & & \\
\hline 13008 & 8300 & 3564 & 13025 & 8314 & 3564 & $0,13 \%$ & $0,17 \%$ & $0,00 \%$ \\
\hline 4908 & 3407 & 920 & 4915 & 3417 & 920 & $0,14 \%$ & $0,29 \%$ & $0,00 \%$ \\
\hline 5833 & 3714 & 1377 & 5842 & 3729 & 1380 & $0,15 \%$ & $0,40 \%$ & $0,22 \%$ \\
\hline 7488 & 4904 & 1415 & 7455 & 4929 & 1415 & $0,44 \%$ & $0,51 \%$ & $0,00 \%$ \\
\hline 10050 & 7800 & 2412 & 10057 & 7823 & 2423 & $0,07 \%$ & $0,29 \%$ & $0,46 \%$ \\
\hline 14395 & 12420 & 4081 & 14388 & 12455 & 4089 & $0,05 \%$ & $0,28 \%$ & $0,20 \%$ \\
\hline 18854 & 17458 & 5767 & 18823 & 17428 & 5783 & $0,16 \%$ & $0,17 \%$ & $0,28 \%$ \\
\hline 22081 & 21776 & 8095 & 22057 & 21778 & 8117 & $0,11 \%$ & $0,01 \%$ & $0,27 \%$ \\
\hline 24623 & 25104 & 9834 & 24590 & 25125 & 9855 & $0,13 \%$ & $0,08 \%$ & $0,21 \%$ \\
\hline 27511 & 29396 & 11060 & 27539 & 29415 & 11116 & $0,10 \%$ & $0,06 \%$ & $0,51 \%$ \\
\hline
\end{tabular}

Berdasarkan perhitungan diatas setelah menggunakan transmitter fiber optik, dapat dilihat bahwa deviasi error terbesar dimiliki oleh Green sebesar 0,226 dan deviasi error terendah dimiliki oleh Red sebesar 0,148.

\section{KESIMPULAN}

Variasi panjang fiber optik yang diberikan menghasilkan kesimpulan bahwa dengan input 1 decoder receiver antena parabola menggunakan panjang kabel fiber optik $2 \mathrm{~m}$ didapatkan nilai rugi-rugi $1,79 \mathrm{~dB}$ dan pada panjang kabel 2 
Jurnal Jaringan Telekomunikasi (Jurnal Jartel) E-ISSN:2654-6531 P-ISSN: 2407-0807 Vol. 10, No.3 (2020) 156-161

$\mathrm{km}$ nilai rugi-rugi sebesar $8,91 \mathrm{~dB}$. Sedangkan dengan input 2 decoder receiver antena parabola menggunakan panjang kabel fiber optik $2 \mathrm{~m}$ didapatkan nilai rugi-rugi 1,93 $\mathrm{dB}$ dan pada panjang kabel $2 \mathrm{~km}$ nilai rugi-rugi sebesar $9,83 \mathrm{~dB}$. Hasil Output layanan TV menggunakan sistem Hybrid Fiber Coaxial didapatkan kualitas sinyal sebesar $74 \%$ dengan jumlah channel sebanyak 49 channel. Sedangkan untuk ratarata deviasi error RGB pada hasil keluaran gambar televisi menggunakan sistem Hybrid Fiber Coaxial deviasi error terbesar dimiliki oleh Green sebesar 0,226\% dan deviasi error terendah dimiliki oleh Red sebesar $0,148 \%$.

Pengaruh output audio dan video sebelum ditambahkan kabel fiber optik terlihat bahwa nilai tegangan output pada audio sebesar 1,792 Volt dan nilai tegangan output pada video sebesar 2,591 Volt. Setelah ditambahkan fiber optik nilai Tegangan output dengan 1 output televisi dan 1 decoder receiver pada panjang $2 \mathrm{~m}$ audio sebesar 1,144 Volt dan video sebesar 1,167 Volt sedangkan pada panjang $2 \mathrm{~km}$ audio sebesar 0,834 Volt dan video sebesar 1,005 Volt. Nilai Tegangan output dengan 2 output televisi dan 2 decoder receiver pada panjang $2 \mathrm{~m}$ audio sebesar 1,121 Volt dan video sebesar 1,148 Volt sedangkan pada panjang $2 \mathrm{~km}$ audio sebesar 0,368 Volt dan video sebesar 0,672 Volt

\section{REFERENSI}

[1] Lynn, Raisa. Yohanes Calvinus. 2017. Kajian Dan Simulasi Prinsip Kerja Coded Orthogonal Frequency Division Multiplexing Untuk Sistem Transmisi Radio Over Fiber. TESLA. 19(2),156-171.

[2] Rajpal, Shivika. Rakesh Goyal. 2017. A Review on Radio-Over-Fiber Technology-Based Integrated (Optical/Wireless) Networks. J.Opt.Commun. 38(1), 19-25.

[3] Sari, Fitri Puspita. Tri Nopiani Damayanti dan Dudung Ruhimat. Perancangan Jaringan HFC Pada FTTH (Fiber To The Home) Dengan Metode FSA dan OSA untuk Layanan CATV.

[4] Nurlaelasari. Erna Sri Sugesti. 2003. Analisis Perancangan Perluasan Jaringan Hybrid Fiber Coax (HFC) Setrasari Bandung Untuk Aplikasi Multiservice.

[5] Gheni, Hassan Muwafaq. Abdullah. Khaldoon Anmar Omar, dkk. 2019. Radio Over Fiber (RoF) Implementation using MZM for Long Distance Communication. ICISCT.

[6] Setyasaputra, Nurmajid. Arif Hidayat. Ahmad Luthfi Hadiyanto, dkk. 2017. Kajian Penggunaan Media Transmisi Fiber Optik untuk Meningkatkan Nilai Perbandingan Penguatan Antena Terhadap Noise. Seminar Nasional Penginderaan Jauh ke-4.

[7] Mubarok, Fiqri Fadlillah. Tri Nopiani Damayanti. Dudung Ruhimat. 2018. Integrasi Sistem Headend HFC Pada Jaringan Fiber To the Home Untuk Layanan TV Broadcast Analog. JETT. 